International Journal of Instruction e-ISSN: 1308-1470 • www.e-iji.net
July $2018 \bullet$ Vol.11, No.3

p-ISSN: 1694-609X

pp. $31-44$

Received: 26/11/2017

Revision: 28/02/2018

Accepted: 04/03/2018

\title{
Metaphorical Perceptions of Middle School Students towards Math
}

\author{
Melike Çetinkaya \\ Ministry of National Education, Ankara, Turkey, melike_0993@hotmail.com
}

Çiğdem Özgören

Ministry of National Education, Ankara, Turkey, tiencigdem5@hotmail.com

\section{Senol Orakcı}

Corresponding author, Ministry of National Education, Ankara, Turkey, senolorak@gmail.com

\section{M. Çağatay Özdemir}

Prof., Gazi University, Department of Educational Sciences, Ankara, Turkey, cagatay@gazi.edu.tr

In every society, the issue of whether an individual can do math has become a central issue. Middle school years, when students' perceptions towards math start to form, have a critical importance for them to develop a positive attitude towards math. The aim of this study is to determine the meaning that the students attributed to the math and to reveal the students' perceptions towards math. Metaphors were also benefited from in order to carry out this aim. The sample of this study was composed of randomly selected 273 students from Yalçın Eskiyapan Middle School located in the district of Keçiören, Ankara in 2015-2016 academic year. When the data obtained from the students were examined, it was seen that the most frequent repeating metaphors were life (38), game (14), book (10), and space (6). The way in which the students explain their metaphors was examined by inductive content analysis. As a result of the analysis, the obtained codes were gathered under four themes as opinions about the content of the math, opinions about the applicability of the math, opinions about the math, and opinions about the teaching of the math. Each theme has two categories, including positive and negative ones.

Keywords: math, metaphor, middle school, students, perception

\section{INTRODUCTION}

Math is a logical system and method. When the definitions of math are compiled, the characteristics and components of math are considered, it is possible to define math as a way of thinking rightly, a communication tool with its own language, a form of 
perception and thinking, or an abstraction instrument that the human brain reveals and needs to be used (Dinç, 2002).

Math is a scientific discipline that gives people reasoning habits (Başer, 1996). In addition to being a theoretical discipline, math is seen as a helpful element for understanding life and the world and for generating ideas (Ernest, 1991). For this reason, the most prominent aim of education-related studies today is to make use of a structure that can help learners understand math (Franke and Kazemi, 2001; Smith, 2000). In addition to its known features, math not only includes numbers, operations, but is also a kind of thinking form and thinking habits that offers a different life style to human beings enabling people to have important skills such as comprehending, thinking, making connections between the events, reasoning, making predictions, and problem solving (Baki, 2001; Güven and Karataş, 2003; Umay, 2003).

According to the education programs of today, teaching math at every level of the schools has become an unquestionable necessity. The importance that countries place on math education is equivalent to importance on teaching their own language. However, the idea that the level of students' achievement in math plays a more decisive role than the achievements they demonstrate in other lessons is widely accepted by societies. For this reason, it can be assumed that everyone has a certain level of knowledge about the necessity of math education (Karaçay, 1985). Math requires thinking. When students think critically in math, they make reasoned decisions or judgments about what to do and think. In other words, students take into account the criteria for a thoughtful decision and do not simply predict or apply a rule without assessing it in detail. That is why it has become one of the most important courses for students at every step of their education life.

The Ministry of National Education (2017) renewed primary school math teaching program and it says in the introductory booklet; "Learning math includes thinking about math, conceptualizing general problem-solving strategies, considering math as an important tool in real life as well as the acquisition of basic concepts and skills. "With the renewed math program, it is aimed to train individuals who can use math in their life, solve problems, share their solutions and thoughts, make team work and develop positive attitude towards math". In math, students use high-level cognitive skills. The fact that math is a course based on the use of high-level cognitive skills often leads students to develop negative attitudes towards this course.

According to Umay (1996), prejudice and fear against math don't pertain to Turkey alone. This results from the nature of math. Educators and mathematicians in other countries are looking for ways to make math teaching more attractive. The problems of math education Turkey stem from the characteristics of math education in our schools beyond the structure of math. Teaching in a vacuum and cliché approaches used in assessment prevents the achievement of the desired level of success of the students and more importantly cause to raise prejudiced individuals against math. Math includes abstract concepts. This characteristic of math makes it difficult for especially younger students to learn. Although the teaching of math starts from the beginning of concrete 
experience and process at the young age, math is directed to abstract thinking as a "mental system".

Math can be done without using symbolic representations in the beginning, but symbolization facilitates abstraction and is indispensable for advanced math. Just as especially children who start the school learn how to read and write via their mother tongue that they acquire, they need to learn how to symbolize math. Numbers are abstract, but the countable objects are concrete. It is of utmost importance to reduce the fear of math by grasping the abstract-concrete relationship with examples from everyday life at an early age. At this point, a confrontational dilemma emerges. Concretization of abstract thinking facilitates teaching math, but removes learners from math. This is why the teaching of math is very difficult (Umay, 1996). Students are alienated from this course by referring to the difficulties that they face to it. In this study, students' feelings and opinions about math are revealed by metaphor application. Metaphors have become a tool frequently used in educational sciences as well as in social sciences, in expressing perceptions about a situation, in which concepts are analyzed and acted out, emotions and thoughts are embodied. In recent years, many researchers have used metaphors to express educational concepts (Jensen, 2006; Cerit, 2008; Botha, 2009; Boyac1, 2009; Saban, 2009; Aydın and Pehlivan, 2010; Ünal and others 2010; Thomas and Beauchamp, 2011; Visser-Wijnveen and others 2012). The number of studies on the use of metaphors related to math is limited (Schink and others 2008; Solomon and Grimley, 2011; Sezgin Memnun, 2013; Sezgin Memnun, 2015; Turhan Türkkan and Yeşilpınar, 2016; Ummanel, 2017). In this sense, the metaphors that will reveal the feelings and thoughts of the middle school students about math are aimed to give information about the students' opinions structure, nature and teaching of this lesson.

The main purpose of this study is to reveal the students' feelings and thoughts about the math and their perceptions of the structure, nature, and teaching of this lesson through the metaphors they used.

In accordance with this purpose, the following questions were sought:

1. What metaphors do the students use to express feelings and thoughts about the learning process of math?

2. What metaphors do the students use to express their thoughts and feelings about the math?

3. What metaphors do the students use to express their perceptions of the nature of the math?

\section{METHOD}

\section{Research Design}

The study that is a descriptive model utilized qualitative research design. In terms of data collection method, the use of metaphors was preferred in the study. According to Morgan (1986), metaphors are used for two purposes: These are descriptive and 
prescriptive (cited as Yıldırım and Şimşek, 2011). In this study, the use of metaphors as a qualitative method of data corresponds more to the descriptive role of it.

\section{Participants}

The study group of this study is composed of 425 middle school students in Yalçın Eskiyapan Secondary School in the district of Ankara, Keçiören. In the study, the students were asked to complete the sentence "math is like ... because.......".

\section{Data Collection Tools and Data Analysis}

The data were obtained by asking the participants to complete the sentence "math is like... because.......". The methods that were used in similar studies in the field used were followed in the analyzes of the data. Saban (2008) in his study examined the analyzes of the data in five steps. These are: 1) the stage of naming and sorting, 2) the stage of sample meta-image compilation, 3) the stage of category development, 4) the stage of providing validity and reliability, and 5) the stage of transferring the data to Microsoft Excel for quantitative data analysis. In the study, metaphors produced by the participants of the study were examined. A list of metaphors was created from the papers completed by the participants in the following stage. Then, the metaphor list was examined and the metaphors were tried to be collected under the themes according to their similarities and differences. In this way, themes were created.

Forceville (2002) stated that in order for a phenomenon to qualify as a metaphor, three questions including "(1) What are its two domains? (2) What is its target domain, and what its source domain? (3) Which feature or (structured) cluster of features can/must be mapped from source to target?" have to be answered clearly. In this study, the answers, which are thought to make no contribution to the understanding of the math concept and to explain no logical basis for the metaphor including more than one metaphor have been eliminated and excluded from the analysis. For example, there are two different metaphors (puzzle and statistics) in the following expression of metaphor: "math is like a puzzle and time, at first you will not understand but as time passes by, you will know the value of it." It was eliminated owing to the fact that it contained more than one metaphor. In addition, the papers that were left empty, were eliminated. As a result, only 273 forms were found to be filled with appropriate metaphors as a result of the examination of the metaphors. $58 \%$ of the answers in qualitative examination belong to the $5^{\text {th }}$ grade, $83 \%$ to the $6^{\text {th }}$ grade, $75 \%$ to the $7^{\text {th }}$ grade, and $57 \%$ to the $8^{\text {th }}$ grade students.

In order to ensure the validity and reliability of the study, metaphor list created was examined in terms of the appropriateness of the themes by a group of experts. With comparison of the opinions of the experts, the reliability of the study was calculated using Miles and Huberman's reliability formula; $[\mathrm{P}=$ ( number of agreements /total number of agreements + disagreements $) \times 100$. When the compliance between the opinions of experts reached $90 \%$ or above, the reliability is considered at a desired level (Saban, 2009). In the study, it was found that there was a consensus in 291 of the 303 metaphor expressions between the experts. The compliance ratio between the experts was found as $91 \%$. This estimate is considered reliable for research (Miles and 
Huberman, 1994). Finally, the variance of the metaphors and themes were examined according to the participants' class level.

\section{FINDINGS}

The most frequent repeated metaphor in the study is "life", which was stated by 38 students. This metaphor is followed by "game", which was stated by 14 students, "book" by 10 students, and "space" by 6 students. Besides, some of the remarkable metaphors of the students were: mother, bitter chocolate, Chinese book, a friend I do not like, steak tartar a la turca, horror film, hell, knot, ripped sock, bogyman, milky way ... Sample positive and negative metaphors developed by the students are given in Table 1.

Table 1

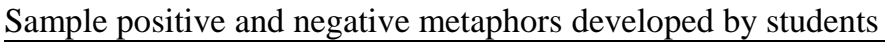

\begin{tabular}{llll}
\hline Positive metaphors & Negative metaphors & \\
\hline Steak tartar a la turca & $\begin{array}{l}\text { Both of them are bitter } \\
\text { but beautiful. If you } \\
\text { have a nice teacher like } \\
\text { pomegranate syrup, you } \\
\text { are still hungry for } \\
\text { success }\end{array}$ & Horror movie & $\begin{array}{l}\text { Horror movies make } \\
\text { people frightened. math } \\
\text { test makes people } \\
\text { frightened, too. }\end{array}$ \\
\hline Water & $\begin{array}{l}\text { It is sometimes } \\
\text { necessary for us to live. }\end{array}$ & Life & $\begin{array}{l}\text { Life is hard, math course } \\
\text { is hard, too. }\end{array}$ \\
\hline Bitter chocolate & $\begin{array}{l}\text { It may be bitter at first } \\
\text { but later it becomes } \\
\text { sweeter; you find math } \\
\text { so difficult at first but } \\
\text { then it makes you have } \\
\text { fun. }\end{array}$ & Dog & $\begin{array}{l}\text { If you do not look after it } \\
\text { or behave badly, it may } \\
\text { bite or attack you, but if } \\
\text { you behave it well give } \\
\text { food to it, it will help and } \\
\text { protect you over time. }\end{array}$ \\
\hline Agriculture & $\begin{array}{l}\text { What you plant now } \\
\text { you will harvest later; } \\
\text { the more you work in } \\
\text { math, the more you } \\
\text { learn. }\end{array}$ & Space & $\begin{array}{l}\text { It is vast and mysterious } \\
\text { like space, and it always } \\
\text { waits to be discovered, } \\
\text { just like the planets in } \\
\text { space. }\end{array}$ \\
\hline
\end{tabular}

When it was examined how the students explained these metaphors, the following data were obtained. When metaphors were analyzed in terms of students' explanations, common codes were collected under 4 main themes. Each main theme consists of two sub-themes as a positive and negative perception. These are;

1. Attitudes towards the content of the math

Positive attitudes towards the content of math, Negative attitudes towards the content of math,

2. Attitudes towards the applicability of math

Positive attitudes about the applicability of the math to life, Negative attitudes about the applicability of the math to life,

3. Attitudes towards teaching math

Positive attitudes towards teaching math, Negative attitudes towards teaching math 


\section{Attitudes towards the overall of math}

Positive attitudes towards the overall of math, Negative attitudes towards the overall of math

The codes given under each theme are as follows;

Positive codes under the theme "attitudes towards the content of the math course" are as follows: being in-depth knowledge, being understandable, being objective, being easy, being everything, being infinite, being brain-boosting and being well proportioned.

Negative codes under the theme "attitudes towards the content of the math course" are as follows: being abstract, being complicated, being progressive, being based on formula, being operational, being elaborate, being difficult, being mysterious and being absurd.

Positive codes under the theme "attitudes towards the applicability of the math to life" are as follows: being necessary, being important, being problem solver, being useful, including general topics, requiring different viewpoints. Negative codes under the theme "attitude towards the applicability of the math to life" are as follows: being useless, being uncertain, being abstract, and requiring effort

Positive codes under the theme "attitudes towards teaching math" are as follows: requiring intelligence, mirror effect (the fact that the children who show a positive attitude during the course get high marks whereas the children who show a negative attitude during the course get low marks) being funny, requiring effort, children's finding Math difficult at first and then finding it easy and enjoyable.

Negative codes under the theme "attitudes towards teaching math are as follows: being boring, requiring reviewing and not tolerating any mistake, mirror effect (the fact that the children who show a positive attitude during the course get high marks whereas the children who show a negative attitude during the course get low marks), children's finding Math difficult at first and then finding it easy and enjoyable.

Positive codes under the theme "attitudes towards the overall of math" are as follows: enjoying it, finding it interesting and rational, a course that is full of surprises.

Negative codes under the theme "attitudes towards the overall of math" are as follows: being bad, not enjoying it, finding it frightening, and having an uncertain attitude towards the course.

When the codes obtained from the words used to describe the metaphors of the students in the study were examined, six codes with the highest frequency are as follows: being difficult ( $\mathrm{f}=42-13,9 \%)$, being funny $(\mathrm{f}=40-13,2 \%)$, being complicated $(\mathrm{f}=25-8,2 \%)$, being boring $(\mathrm{f}=25-7,9 \%)$, containing everything within itself $(\mathrm{f}=22-7,2 \%)$, being easy $(\mathrm{f}=12-4 \%)$. 
Table 2

Frequency table for codes formed from students' metaphors

\begin{tabular}{|c|c|c|c|c|c|c|c|}
\hline Positive Codes & $\mathrm{f}$ & $\begin{array}{l}\text { Percentage } \\
\text { of all codes } \\
(\%)\end{array}$ & $\begin{array}{l}\text { Percentage } \\
\text { of positive } \\
\text { codes }(\%)\end{array}$ & Negative Codes & $\mathrm{f}$ & $\begin{array}{l}\text { Percentage } \\
\text { of all codes } \\
(\%)\end{array}$ & $\begin{array}{l}\text { Percentage } \\
\text { of negative } \\
\text { codes }(\%)\end{array}$ \\
\hline Being funny & 40 & 13,16 & 27,59 & Being difficult & 42 & 13,82 & 26,42 \\
\hline Being everything & 22 & 7,24 & 15,17 & Being complicated & 25 & 8,22 & 15,72 \\
\hline Being necessary & 20 & 6,58 & 13,79 & Being boring & 24 & 7,89 & 15,09 \\
\hline $\begin{array}{l}\text { Being in-depth } \\
\text { knowledge }\end{array}$ & 12 & 3,95 & 8,28 & Being operational & 17 & 5,59 & 10,69 \\
\hline Being easy & 12 & 3,95 & 8,28 & Being frightening & 13 & 4,28 & 8,18 \\
\hline I like it & 9 & 2,96 & 6,21 & Requiring effort & 12 & 3,95 & 7,55 \\
\hline Mirror effect & 8 & 2,63 & 5,52 & Being mysterious & 6 & 1,97 & 3,77 \\
\hline Being important & 5 & 1,64 & 3,45 & I don't like it & 5 & 1,64 & 3,14 \\
\hline Being brain-boosting & 5 & 1,64 & 3,45 & Being bad & 4 & 1,32 & 2,52 \\
\hline $\begin{array}{l}\text { Being difficult at first } \\
\text { and then easy and } \\
\text { enjoyable }\end{array}$ & 4 & 1,32 & 2,76 & Being changeable & 4 & 1,32 & 2,52 \\
\hline Being good & 3 & 0,99 & 2,07 & Being progressive & 2 & 0,66 & 1,26 \\
\hline Being objective & 2 & 0,66 & 1,38 & Being abstract & 1 & 0,33 & 0,63 \\
\hline Being soothing & 1 & 0,33 & 0,69 & Being uncertain & 1 & 0,33 & 0,63 \\
\hline Being problem solver & 1 & 0,33 & 0,69 & $\begin{array}{l}\text { Requiring not } \\
\text { tolerating any mistake }\end{array}$ & 1 & 0,33 & 0,63 \\
\hline \multirow[t]{2}{*}{ Being interesting } & 1 & 0,33 & 0,69 & Being easily forgotten & 1 & 0,33 & 0,63 \\
\hline & & & & $\begin{array}{l}\text { Being difficult at first } \\
\text { and then easy and } \\
\text { enjoyable }\end{array}$ & 1 & 0,33 & 0,63 \\
\hline Total & 145 & 47,70 & 100,00 & Total & 159 & 52,30 & 100,00 \\
\hline
\end{tabular}

When six codes with the highest frequency were examined in terms of class level, it was observed that the repetition of the codes "being difficult, being complicated, being boring and being funny" increased in the $5^{\text {th }}, 6^{\text {th }}$, and $7^{\text {th }}$ class levels as the class level increased.

When the repetition numbers of these codes reached in the $8^{\text {th }}$ class, numerical values close to the level of $6^{\text {th }}$ class were obtained.

When the codes "being everything" and " being necessary " were examined in terms of class level, it was determined that the number of repetitions of codes increased in $5^{\text {th }}$ and $6^{\text {th }}$ class levels as the class level increased. The frequency of repetition of the code "being everything" significantly reduced in $7^{\text {th }}$ and $8^{\text {th }}$ classes.

The number of "being necessary" code decreased 1 in $7^{\text {th }}$ class and increased 5 in $8^{\text {th }}$ class. 
Table 3

Frequency table for codes formed from students' metaphors (Class-based)

\begin{tabular}{|c|c|c|c|c|c|c|c|c|}
\hline & Positive Codes & $\mathrm{f}$ & $\begin{array}{l}\text { Percentage } \\
\text { of all codes } \\
(\%)\end{array}$ & $\begin{array}{l}\text { Percentage } \\
\text { of positive } \\
\text { codes }(\%)\end{array}$ & Negative Codes & $\mathrm{f}$ & $\begin{array}{l}\text { Percentage } \\
\text { of all codes } \\
(\%)\end{array}$ & $\begin{array}{l}\text { Percentage } \\
\text { of negative } \\
\text { codes }(\%)\end{array}$ \\
\hline \multirow{11}{*}{$\begin{array}{l}5^{\text {th }} \\
\text { Grade }\end{array}$} & Being funny & 7 & 12,3 & 20,6 & Being complicated & 5 & 8,8 & 21,7 \\
\hline & Being everything & 5 & 8,8 & 14,7 & Being frightening & 5 & 8,8 & 21,7 \\
\hline & Being necessary & 5 & 8,8 & 14,7 & Being difficult & 4 & 7,0 & 17,4 \\
\hline & Being in-depth knowledge & 4 & 7,0 & 11,8 & Being operational & 2 & 3,5 & 8,7 \\
\hline & I like it & 4 & 7,0 & 11,8 & Requiring effort & 2 & 3,5 & 8,7 \\
\hline & Mirror effect & 4 & 7,0 & 11,8 & Being mysterious & 1 & 1,8 & 4,3 \\
\hline & Being important & 2 & 3,5 & 5,9 & I don't like it & 1 & 1,8 & 4,3 \\
\hline & Being easy & 1 & 1,8 & 2,9 & Being bad & 1 & 1,8 & 4,3 \\
\hline & $\begin{array}{l}\text { Being difficult at first and } \\
\text { then easy and enjoyable }\end{array}$ & 1 & 1,8 & 2,9 & Being changeable & 1 & 1,8 & 4,3 \\
\hline & Being good & 1 & 1,8 & 2,9 & $\begin{array}{l}\text { Being difficult at first } \\
\text { and then easy and } \\
\text { enjoyable }\end{array}$ & 1 & 1,8 & 4,3 \\
\hline & Total & 34 & 59,6 & 100,0 & Total & 23 & 40,4 & 100,0 \\
\hline \multirow{12}{*}{$\begin{array}{l}6^{\text {th }} \\
\text { Grade }\end{array}$} & Being funny & 11 & 12,9 & 27,5 & Being difficult & 10 & 11,8 & 22,2 \\
\hline & Being everything & 9 & 10,6 & 22,5 & Being complicated & 10 & 11,8 & 22,2 \\
\hline & Being necessary & 8 & 9,4 & 20,0 & Being boring & 8 & 9,4 & 17,8 \\
\hline & Being in-depth knowledge & 3 & 3,5 & 7,5 & Being operational & 4 & 4,7 & 8,9 \\
\hline & I like it & 2 & 2,4 & 5,0 & Being frightening & 4 & 4,7 & 8,9 \\
\hline & Being important & 2 & 2,4 & 5,0 & Requiring effort & 4 & 4,7 & 8,9 \\
\hline & Being easy & 1 & 1,2 & 2,5 & Being mysterious & 3 & 3,5 & 6,7 \\
\hline & $\begin{array}{l}\text { Being difficult at first and } \\
\text { then easy and enjoyable }\end{array}$ & 1 & 1,2 & 2,5 & I don't like it & 1 & 1,2 & 2,2 \\
\hline & Being good & 1 & 1,2 & 2,5 & Being abstract & 1 & 1,2 & 2,2 \\
\hline & Being soothing & 1 & 1,2 & 2,5 & & & & \\
\hline & Being problem solver & 1 & 1,2 & 2,5 & & & & \\
\hline & Total & 40 & 47,1 & 100 & Total & 45 & 52,9 & 100 \\
\hline \multirow{12}{*}{$\begin{array}{l}7^{\text {th }} \\
\text { Grade }\end{array}$} & Being funny & 17 & 18,7 & 35,4 & Being difficult & 16 & 17,6 & 37,2 \\
\hline & Being easy & 8 & 8,8 & 16,7 & Being operational & 7 & 7,7 & 16,3 \\
\hline & Being everything & 5 & 5,5 & 10,4 & Being boring & 6 & 6,6 & 14,0 \\
\hline & Being in-depth knowledge & 4 & 4,4 & 8,3 & Being complicated & 4 & 4,4 & 9,3 \\
\hline & Mirror effect & 4 & 4,4 & 8,3 & Being frightening & 2 & 2,2 & 4,7 \\
\hline & Being brain-boosting & 4 & 4,4 & 8,3 & Requiring effort & 2 & 2,2 & 4,7 \\
\hline & Being necessary & 2 & 2,2 & 4,2 & Being progressive & 2 & 2,2 & 4,7 \\
\hline & I like it & 2 & 2,2 & 4,2 & Being bad & 1 & 1,1 & 2,3 \\
\hline & $\begin{array}{l}\text { Being difficult at first and } \\
\text { then easy and enjoyable }\end{array}$ & 2 & 2,2 & 4,2 & Being changeable & 1 & 1,1 & 2,3 \\
\hline & & & & & Being uncertain & 1 & 1,1 & 2,3 \\
\hline & & & & & $\begin{array}{l}\text { Requiring not } \\
\text { tolerating any mistake }\end{array}$ & 1 & 1,1 & 2,3 \\
\hline & Total & 48 & 52,7 & 100,0 & Total & 43 & 47,3 & 100,0 \\
\hline \multirow{12}{*}{$\begin{array}{l}8^{\text {th }} \\
\text { Grade }\end{array}$} & Being funny & 5 & 7,1 & 22,7 & Being difficult & 12 & 17,1 & 25,0 \\
\hline & Being necessary & 5 & 7,1 & 22,7 & Being boring & 10 & 14,3 & 20,8 \\
\hline & Being everything & 3 & 4,3 & 13,6 & Being complicated & 6 & 8,6 & 12,5 \\
\hline & Being easy & 2 & 2,9 & 9,1 & Being operational & 4 & 5,7 & 8,3 \\
\hline & Being in-depth knowledge & 1 & 1,4 & 4,5 & Requiring effort & 4 & 5,7 & 8,3 \\
\hline & I like it & 1 & 1,4 & 4,5 & I don't like it & 3 & 4,3 & 6,3 \\
\hline & Being important & 1 & 1,4 & 4,5 & Being frightening & 2 & 2,9 & 4,2 \\
\hline & Being brain-boosting & 1 & 1,4 & 4,5 & Being mysterious & 2 & 2,9 & 4,2 \\
\hline & Being good & 1 & 1,4 & 4,5 & Being bad & 2 & 2,9 & 4,2 \\
\hline & Being objective & 1 & 1,4 & 4,5 & Being changeable & 2 & 2,9 & 4,2 \\
\hline & Being interesting & 1 & 1,4 & 4,5 & Being easily forgotten & 1 & 1,4 & 2,1 \\
\hline & Total & 22 & 31,4 & 100 & Total & 48 & 68,6 & 100 \\
\hline
\end{tabular}

International Journal of Instruction, July $2018 \bullet$ Vol.11, No.3 
When Table 3 is examined, it can be seen that the students produced more positive metaphors about math at the $5^{\text {th }}$ class and the ratio of these positive codes decreased at the $6^{\text {th }}$ grade. Positive codes that were relatively higher than the $6^{\text {th }}$ class at the $7^{\text {th }}$ class fell to $31.4 \%$ at the $8^{\text {th }}$ class. It can be concluded that students had a more negative perception towards math at the $8^{\text {th }}$ grade. According to Table 3 again, the most positive repetitive code in all class levels is "being funny".

"Being necessary" and "containing everything within itself" are positive codes that students often emphasized in all class levels. At class levels except $5^{\text {th }}$ class, "being difficult" was the most repeated negative code for math. At all class levels, the codes "being complicated", "being operational" and "being boring" are often found in the upper places of negative codes recurring frequently. Some of the metaphors used in obtaining these codes are as follows:

"Math is like agriculture, because what you plant now you will harvest later; the more you work in math, the more you learn" (mirror effect)

"Math is like bitter chocolate, because bitter chocolate may be bitter at first but later it becomes sweeter; you find math so difficult at first but then it makes you have fun" (finding Math difficult at first and then easy and enjoyable)

"Math is like life. Life is difficult; math is difficult, too." (Being difficult)

"Math is like water because it is sometimes necessary for us to live". (Being necessary)

"Math is like steak tartar a la turca because steak tartar a la turca and math are bitter but beautiful. If you have a nice teacher like pomegranate syrup, you are still hungry for success". (being good)

\section{DISCUSSION AND CONCLUSION}

Metaphor is one of the basic mental models that shapes people's thoughts about the reality and the world. According to Lakoff and Johnson (2003), who first studied metaphors comprehensively, metaphor is a phenomenon that penetrates everyday life, not only in language but also in thought and acts. Metaphors enable people to compare abstract or complex phenomena with more concrete or experienced ones and thanks to this, they help to develop an understanding of the phenomena unknown (Ocak and Gündüz, 2006). The perceptions of math of middle school $5^{\text {th }}, 6^{\text {th }}, 7^{\text {th }}$ and $8^{\text {th }}$ grade students were revealed through metaphors in the study. When metaphors were examined, common codes were collected under 4 main themes. Each main theme consists of 2 sub-themes pertaining to that theme as positive perception and negative perception. These are; 1. Attitudes towards the content of the math 1.1. Positive attitudes towards the content of math, 1.2. Negative attitudes towards the content of math, 2. Attitudes towards the applicability of math 2.1. Positive attitudes about the applicability of the math to life, 2.2. Negative attitudes about the applicability of the math to life, 3. Attitudes towards teaching math 3.1. Positive attitudes towards teaching math 3.2. Negative attitudes towards teaching math 4. Attitudes towards the overall of math 4.1. Positive attitudes towards the overall of math and 4.2. Negative attitudes towards the overall of math. When all the metaphors obtained are examined, it is seen 
that some of them are positive whereas others are negative. Students' negative perceptions could be an outcome of the fact that math as a subject is considered to be the most important one by students, parents and society at large, and the fact that male students are more inclined to solve problems than female students; a behavior supported by Turkish patriarchal family structure. Among other reasons for the negative perceptions, the fact that the assessment of student achievement in math course is based on exams and that the difficulty levels of exams that are taken into account in school selection are higher than those indicated in the curriculum can be mentioned. Students' fear of math course, their fear of failure in exams for passing courses, their acknowledgement of failure, a feeling of dislike for math that results from their not being successful in math can be listed among other potential sources of the negative perceptions. When the frequency of the codes is considered, the code with the highest frequency is the "difficult" code, indicating that the students see math as a difficult course. The results of this research coincide with the results of the study by SezginMemnun (2015) that investigates middle school students' metaphors towards math problem. Similar findings are seen in Oflaz (2011) as well as Akın and Cancan's (2007) studies. Moreover, almost half of the codes in this study are positive and half of them are composed of codes with negative perceptions. This shows that half of the students developed positive perceptions towards math and the other half developed negative perceptions towards math. In different studies, it is supported by the determination of students' having difficulty in math, their fear of math and negative attitude towards it (Dursun and Dede, 2004; Gür and others 2014; Stylianides and Stylianides, 2014; Şenol and others 2015; Üredi and Üredi, 2005). When the negative codes given by the students are examined according to their class levels, it is seen that the most negative opinion was expressed at the level of $8^{\text {th }}$ grade.

The reason for this is thought to be the result of the stress of the exam "Transition from Basic Education to Secondary Education" (BESE) applied on the $8^{\text {th }}$ grade (which was in use at the time of this study and has recently been abolished). Further research needs to be conducted about it. When the positive codes given by the students are examined at the class level, the most positive code is at the level of $5^{\text {th }}$ grade. This may be due to the fact that math courses in the $5^{\text {th }}$ grade curriculum are taught with an understanding based on scenarios. It may also be resulted from that math courses are based on realistic math education composed of activities. In addition, teachers can be more aware of the young age at this class level of the students and perhaps teach math courses in a more funny way and behave students in a more understanding way. The ratio of positive thoughts decreases to $5^{\text {th }}, 7^{\text {th }}, 6^{\text {th }}$ and $8^{\text {th }}$ grade levels respectively. In other words, it cannot be said that the class level and the perception towards math are negatively related to each other, but the fact that the most positive opinions are at the $5^{\text {th }}$ grade level and the most negative opinions are at the $8^{\text {th }}$ grade shows that high positive perception at the $5^{\text {th }}$ grade level which is the beginning of the middle school, drops to very low values at the $8^{\text {th }}$ grade level. This may be the subject of further research. The fact that the $6^{\text {th }}$ grade students have more negative thoughts than the $7^{\text {th }}$ grade students may be due to the fact that the $6^{\text {th }}$ grade curriculum is very intense, the number of weekly course hours is not sufficient, real life scenarios as well as the activities that teachers are required to use are 
not employed during the course by teachers and they teach math courses using direct instruction technique instead of the entertaining teaching techniques due to their worries about the application of curriculum completely on time. In a similar study of Gür, Hangül and Kara (2014), it appears that positive or negative beliefs developed towards math have increased somewhat in the transition from middle school to high school. More in-depth and advanced information about aforementioned ones may be the subject of further research.

In sum, the following suggestions can be done to prevent students from having negative thoughts about math course.

- Assesments in math course should be based on process and product rather than being only exam-oriented.

- The adoption of an education system that includes the alternative assessment such as portfolios and project work should be realized.

- The selection of high school students should be based on the alternative assesment of the students rather than a single exam.

- The reduction of curriculum intensity in the $6^{\text {th }}$ grade math course should be considered.

\section{REFERENCES}

Akın, Y. \& Cancan, M. (2007). Matematik öğretiminde problem çözümüne yönelik öğrenci görüşleri analizi. Atatürk Üniversitesi Kazım Karabekir Eğitim Fakültesi Dergisi, 16, 374-390.

Aydın, İ. S. \& Pehlivan, A. (2010). Türkçe öğretmeni adaylarının "öğretmen" ve "öğrenci" kavramlarına ilişkin kullandıkları metaforlar. International Periodical for the Languages, Literature and History of Turkish or Turkic, 5 (3), 818-842.

Baki, A. (2001). Bilişim Teknolojisi Işığı Altında Matematik Eğitiminin Değerlendirilmesi. Milli Ĕ̆itim Dergisi, 149, 26-31.

Başer N.(1996). Ders Geçme ve Kredi Sisteminde Lise Öğrencileri için Bir Matematik Başarı Testi Tasarımı ve Uygulanabilirliğinin Araştırılması, Yayınlanmamış Doktora Tezi, D.E.Ü. Sosyal Bilimler Enstitüsü. İzmir.

Botha, E. (2009). Why metaphor matters in education. South African Journal of Education, 29, 431-444.

Boyac1, A. (2009). İlköğretim okulu öğretmenlerinin eğitim planlaması süreçlerine yönelik kullandıkları metaforlar. Selçuk Üniversitesi Sosyal Bilimler Enstitüsü Dergisi 21, 111-124.

Cerit, Y. (2008). Öğrenci, öğretmen ve yöneticilerin müdür kavramı ile ilgili metaforlara ilişkin görüşleri. Ĕgitim ve Bilim, 33 (147), 3-13. 
Dinç, B. (2002). Okulöncesi Eğitimin 4-5 Yaş Çocuğunun Sosyal Geliş̧mine Etkileri Konusunda Öğretmen Görüşleri. OMEP 2003 Dünya Konsey Toplantısı ve Konferans1, Kuşadası, 2002. Dört Sifirdan Üçü Erkek. Radikal Gazetesi. 6 Ağustos 2004.

Dursun, Ş. \& Dede, Y. (2004). Öğrencilerin matematikte başarısını etkileyen faktörler: Matematik öğretmenlerinin görüşleri bakımından. Gazi Eğitim Fakültesi Dergisi, 24 (2), 217-230.

Ernest, P. (1991). The philosophy of maths education. Hampshire: The Falmer Press.

Forceville, C. (2002). The identification of target and source in pictorial metaphors. Journal of Pragmatics, 34, 1-14.

Franke, L. \& Kazemi, E. (2001). Learning to Teach Maths: Focus on Student Thinking. Theory into Practice, 40 (2), 102-109.

Gür, H., Hangül, T. \& Kara, A. (2014). Ortaokul ve lise öğrencilerinin "matematik kavramına ilişkin sahip oldukları meteforların karşılaştırılması. The Journal of Academic Social Science Studies, 25 (1), 427-444.

Güven, B. \& Karataş, İ. (2003). Learning Geometry with Dynamic Geometry Software Cabri: Students“ perceptions, The Turkish Online Journal of Educational Technology, 2 (2).

Jensen, D. F. (2006). Metaphors as a bridge to understanding educational and social contexts. International Journal of Qualitative Methods, 1 (5).

Karaçay, T. (1985). Matematik öğretiminin bugünkü durumu ve değerlendirilmesi. Matematik Öğretimi ve Sorunlan, Türk Eğitim Derneği III. Öğretim Toplantısı, Ankara: Yorum Basın-Yayın.

Lakoff, G., \& Johnson, M. (2003). Metaphors We Live By, $2^{\text {nd }}$ ed. University of Chicago Press, Chicago

MEB. (2017). İlköğretim Matematik Dersi (6-7-8 Sinfflar) Öğretim Programı, İstanbul: MEB Yayınları.

Miles, M. B., \& Huberman, A. M. (1994). Qualitative data analysis. Thousand Oaks, CA: Sage.

Ocak, G., \& Gündüz, M., (2006). Eğitim Fakültesini Yeni Kazanan Öğretmen Adaylarının Öğretmenlik Mesleği Dersini Almadan Önce ve Aldıktan Sonra Öğretmenlik Mesleği Hakkındaki Metaforlarının Karşılaştııılması, AKÜ Sosyal Bilimler Dergisi, 8(2).

Oflaz, G. (2011). Ilköğretim ögrencilerinin 'matematik' ve 'matematik ögrretmeni' kavramlarına iliskin metaforik algilarl. Paper presented at the 2nd International Conference on New Trends in Education and Their Implications, Antalya. Retrieved from http://iconte.org/FileUpload/ks59689/File/156..pdf. 
Saban, A. (2008). Okula İlişkin Metaforlar. Kuram ve Uygulamada Eğitim Yönetimi, 55, 459- 496.

Saban, A. (2009). Öğretmen adaylarının öğrenci kavramına ilişkin sahip oldukları zihinsel imgeler. Türk Eğitim Bilimleri Dergisi, 7 (2), 281-326.

Schinck, A. G., Neale, H. W., Pugalee, D. K., \& Cifarelli, V. V. (2008). Using metaphors to unpack student beliefs about mathematics. School Science and Mathematics, 108(7), 326-333.

Sezgin Memnun, D. (2013). Altıncı sınıf öğrencilerinin matematik problemine ilişkin sahip oldukları metaforlar. International Symposium on Changes and New Trends in Education. Konya, Turkey.

Sezgin-Memnun, D. (2015). Ortaokul öğrencilerinin matematik problemine ilişkin sahip oldukları metaforlar ve bu metaforların sınıf düzeylerine göre değişimi. Necatibey Ĕgitim Fakültesi Elektronik Fen ve Matematik Ĕ̈itimi Dergisi, 9 (1), 351-374.

Smith, M.(2000). Redefining success in maths teaching and learning. Maths Teaching in the Middle School, 5 (6).

Solomon, C., \& Grimley, M. (2011). Metaphors used by year 5 and 6 children to depict their beliefs about maths. Mathematics: Traditions and [New] Practices Conference. Alice Springs, Australia.

Stylianides, A.J. \& Stylianides, G.J. (2014). Impacting positively on students' mathematical problem solving beliefs: An instructional intervention of short duration. Journal of Mathematical Behavior, 33, 8- 29.

Şenol, A., Dündar, S., Kaya, İ., Gündüz, N. \& Temel, H.(2015). Ortaokul matematik öğretmenlerinin matematik korkusu ile ilgili görüşlerinin incelenmesi. Eğitimde Kuram ve Uygulama, 11 (2), 653-672.

Thomas, L., \& Beauchamp, C. (2011). Understanding new teachers' professional identities through metaphor. Teaching and Teacher Education, 27, 762-769.

Turhan Türkkan, B., \& Yeşilpınar Uyar, M. (2016). Ortaokul öğrencilerinin matematik problemi kavramına yönelik metaforları. Çukurova Üniversitesi Ĕgitim Fakültesi Dergisi, 45(1), 99-130.

Umay A, (2003). Matematiksel Muhakeme Yeteneği, Hacettepe Üniversitesi Eğitim Fakültesi Dergisi, 24, 234-243.

Umay, A.(1996). Matematik Eğitimi ve Ölçülmesi. Hacettepe Üniversitesi Eğitim Fakültesi Dergisi, 12, 145-149.

Ummanel, A. (2017). Metaphorical Perceptions of Preschool, Elementary and Secondary School Children About Science and Mathematics. EURASIA Journal of Mathematics Science and Technology Education, 13(8):4651-4668 
Ünal, A., Yıldırım, A. \& Çelik, M. (2010). İlköğretim okulu müdür ve öğretmenlerinin velilere ilişkin algılarının analizi. Selçuk Üniversitesi Sosyal Bilimler Enstitüsü Dergisi, 23, 261-272.

Üredi, I. \& Üredi, L. (2005). İlköğretim 8. sınıf öğrencilerinin öz-düzenleme stratejileri ve motivasyonel inançlarının matematik başarısını yordama gücü. Mersin Üniversitesi Eğitim Fakültesi Dergisi, 1 (2), 250-260.

Visser-Wijnveen, G. J., Van Driel, J. H., Van der Rijst, R. M., Verloop, N., \& Visser, A. (2012). The relationship between academics' conceptions of knowledge, research and teaching-a metaphor study. Teaching in Higher Education, 14 (6), 673-686.

Yıldırım, A. \& Şimşek, H. (2011). Sosyal Bilimlerde Nitel Araştırma Yöntemleri (8. Bask1). Ankara: Seçkin Yayıncılık. 